\title{
THE LIVING STANDARDS OF THE POPULATION OF THE RUSSIAN FEDERATION
}

\author{
E.Grishina, S.Misikhina
}

The real disposable money income of the population over the first 7 months of 2013 rose by $4.3 \%$ on the corresponding period of 2012, which happened due to an increase in wages and a somewhat less pronounced increase in pensions. The year 2013 saw a persisting though negligible upward trend in the movement of the money income inequality index. The alterations introduced in 2013 into the methodology applied for estimating the subsistence level resulted in its upward adjustment which, in its turn, pushed up the poverty level indices. When calculated in accordance with the previously applied subsistence level estimation methodology, the poverty level indices for Q1 2013 turned out to be lower than the corresponding indices for Q1 2012.

The money income of the population. The nominal per capita index of the population's money income in July 2013 amounted to $\mathrm{Rb} 25,072$, which is by $3.2 \%$ below its June value. The decline of the population's real disposable money income over that period amounted to $4.9 \%$. In 2012, the July drop of that index on its previous month's value was more noticeable $-6.7 \%$.

Growth of the population's real disposable money income in Q2 2013 resulted in its climb, over the second half year of 2013 , by $4.4 \%$ on the corresponding period of last year.

Over the first 7 months of 2013, the population's real disposable money income increased by $4.3 \%$.

Table 1

CHANGES IN THE REAL DISPOSABLE MONEY INCOME, \%

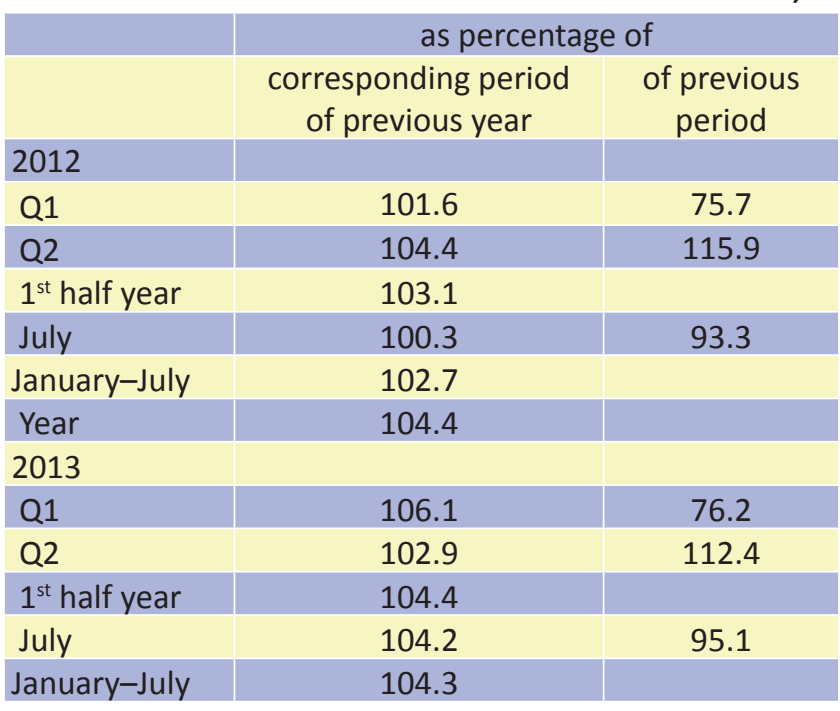

Source: data released by Rosstat.

By comparison with July 2012, in July 2013 the share of mandatory payments and fees in total money income rose from $11.1 \%$ to $11.9 \%$. Over the period of JanuaryJuly 2013, the purchasing power of per capita money income declined on the same period of 2012 with regard to some foodstuffs like bread (by 4\%), carrots (by 10\%), onions (by 12\%), fresh white head cabbage (by $17 \%$ ), potatoes (by 18\%), while the same index for pork and frozen fish increased by $14 \%$ and $12 \%$ respectively.

The average monthly charged wage in July 2013 was at the level of $\mathrm{Rb} 30,366$, having increased on the corresponding period of last year by $13.5 \%$, and over the period of January-uly 2013 - by $12.9 \%$. The real average monthly charged wage in Q2 2013 rose by $9 \%$ on Q1 2013, and then in July it slightly declined - by $2.8 \%$ on June 2013. The real wage over the period of January-July 2013 was above its level recorded over the corresponding period of last year by $5.5 \%$.

In spite of the fact that in the first half year of 2013 the average monthly charged wage index rose significantly on the corresponding period of 2012 in some areas of economic activity like education and healthcare \& social services (by $24 \%$ and $17 \%$ respectively), the actual wage level in these areas amounts to only $79 \%$ of Russia's average.

In the first half year of 2013, labor pension indexation was carried out twice:

- on 1 February 2013, labor pensions were increased by $6.6 \%$;

- on 1 April, due an increase in the RF Pension Fund's revenues, an additional upward adjustment of labor pension size by $3.3 \%$ was carried out.

State pensions, including social pensions, from 1 April 2013 were increased by $1.81 \%$.

In June 2013, the average size of allotted pension amounted to $\mathrm{Rb} 10,019$, having risen on June 2012 by 9.5\%. The growth of the real size of allotted pension over Q1 2013 amounted to $2.4 \%$, that over Q2 - to 3\%. Over the first half year of 2013, the real size of allotted pension increased on the corresponding period of the previous year by $2.5 \%$.

Socioeconomic differentiation. In 2013, the trend of negligibly increasing inequality in the distribution of the population's money incomes remained unchanged. 
DISTRIBUTION OF THE AGGREGATE VOLUME OF POPULATION'S MONEY INCOME, \%

\begin{tabular}{|c|c|c|c|c|c|c|c|c|}
\hline & \multicolumn{3}{|c|}{2011} & \multicolumn{3}{|c|}{2012} & \multicolumn{2}{|c|}{2013} \\
\hline & Q1 & $\begin{array}{l}1^{\text {st }} \text { half } \\
\text { year }\end{array}$ & Year & Q1 & $\begin{array}{l}1^{\text {st }} \text { half } \\
\text { year }\end{array}$ & Year & Q1 & $\begin{array}{l}1^{\text {st }} \text { half } \\
\text { year }\end{array}$ \\
\hline Money income - total & 100 & 100 & 100 & 100 & 100 & 100 & 100 & 100 \\
\hline \multicolumn{9}{|l|}{$\begin{array}{l}\text { including between } \\
\text { population quintiles }\end{array}$} \\
\hline first quintile (lowest income group) & 5.6 & 5.5 & 5.2 & 5.5 & 5.3 & 5.2 & 5.5 & 5.3 \\
\hline second quintile & 10.4 & 10.2 & 9.9 & 10.3 & 10.1 & 9.8 & 10.3 & 10 \\
\hline third quintile & 15.4 & 15.2 & 14.9 & 15.2 & 15.1 & 14.9 & 15.2 & 15 \\
\hline fourth quintile & 22.8 & 22.7 & 22.6 & 22.7 & 22.6 & 22.5 & 22.7 & 22.6 \\
\hline fifth quintile (highest incomes) & 45.8 & 46.4 & 47.4 & 46.3 & 46.9 & 47.6 & 46.3 & 47.1 \\
\hline $\begin{array}{l}\text { Gini coefficient (income } \\
\text { concentration index) }\end{array}$ & 0.398 & 0.405 & 0.417 & 0.403 & 0.411 & 0.42 & 0.404 & 0.414 \\
\hline R/P 10\%, times & 14 & 14.8 & 16.2 & 14.5 & 15.4 & 16.4 & 14.7 & 15.7 \\
\hline
\end{tabular}

Source: data released by Rosstat.

Over the first half year of 2013, the income inequality indices rose on the first half year of 2012 as follows:

- the Gini coefficient: from 0.411 to 0.414 ;

- the ratio of the average income of the richest $10 \%$ to the poorest $10 \%$ (R/P $10 \%)$ : from 15.4 to 15.7 .

All other conditions being equal, such an increase in the values of these indices may trigger their growth on 2012 that will push them up to the level of $0.422-0.423$ for the Gini coefficient and 16.6-16.7 for R/P 10\%.

The increasing inequality in the distribution of the population's money incomes has largely been caused by the accelerated income growth rate in the fifth quintile (highest incomes) by comparison with that in the other population groups with lower incomes. The accelerated income growth in the most wealthy group of the population resulted in a situation where the fifth quintile's share in the aggregate volume of population's money income over the first half year of 2013 rose on the corresponding period of last year from $46.9 \%$ to $47.1 \%$, while the shares of the second and third quintiles declined by 0.1 p.p. each.

Subsistence level and poverty. The subsistence and poverty level estimates require some additional explanations as the methodology for calculating the subsistence level has been altered from the year 2013 onwards. Thus, the share of food in the consumer basket was increased due to the markedly raised consumption norms with regard to expensive foodstuffs (meat, fish, dairies, fruits) and slightly reduced shares of other foods (bread, potatoes), as well as the higher shares of non-food products and lower relative shares of services.

The alterations introduced in the methodology for calculating the subsistence level resulted in its higher value by comparison with that calculated in accordance
Table 3

\section{NUMBER OF PEOPLE WITH INCOMES BELOW} SUBSISTENCE LEVEL

\begin{tabular}{|l|c|c|}
\hline & Million & As \% of total population \\
\hline Q1 & & \\
\hline 1st half year & 19.1 & 13.5 \\
\hline Year & 15.7 & 12.5 \\
\hline 2013 & & 11.0 \\
\hline Q1 & 19.6 & 13.8 \\
\hline
\end{tabular}

Source: data released by Rosstat.

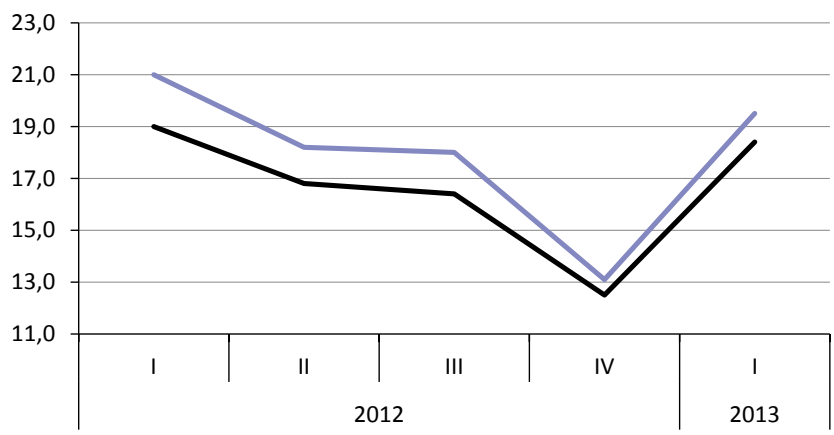

-based on the subsistence level estimated in accordance with the consumer basket established by Federal Law of 31 March 2006, No 44-03 "On the Consumer Basket Across the Russian Federation"

—based on the subsistence level estimated in accordance with the consumer basket established by Federal Law of 3 December 2012, No 227-03 "On the Consumer Basket Across the Russian Federation"

Fig. 1. Changes in the Number of Population with Per capita Income Below Below Subsistence Level, million persons

with the previously applied methodology, which in its turn pushed up the poverty indices.

The subsistence level indices in Q1 2013 were as follows: monthly average for total population - $\mathrm{Rb} 7,095$; monthly average for able-bodied population $-\mathrm{Rb} 7,633$; 
monthly average for retired population - $\mathrm{Rb} 5,828$; and monthly average for children - Rb 6,859.

The poverty index in Q1 2013 was at the level of $19.6 \mathrm{~m}$, or $13.8 \%$ total population - i.e. higher than in Q1 2012. However if the poverty index is estimated in accordance with the previously applied methodology, its value will become actually lower than in Q1 2012, thus giving rise to hopes that, all other conditions being equal, it may become stabilized at its current level or even continue its downward movement over the course of 2013.

Economic activity, employment and unemployment levels. As shown by the results of a sample survey of the population addressing employment issues, as of the second week of July 2013 the number of economically active people in the $15-72$ age groups amounted to $75.8 \mathrm{~m}$, or to $68.5 \%$ of the population belonging to the $15-72$ age groups, or approximately $53 \%$ of the total population.

While over the period of January-March 2013 the economic activity of the population was higher than in the corresponding periods of 2012 by $0.3-0.5$ p.p., in May and June 2013 the population's economic activity level was lower by $0.7-0.8$ p.p. than in the corresponding periods of 2012.

It is noteworthy that the most pronounced decline in the level of economic activity was noted among women (by 1.2 p.p. in June 2013 on June 2012), while men's economic activity level in June 2013 dropped by 1.1 p.p. on the same period of 2012.

In accordance with the results of the sample survey of the population addressing employment issues, in July 2013 the employment level for total population was $652 \%$.

In January-March 2013, the level of employment was by $0.5-0.9$ p.p. higher than the same index for the corresponding period of 2012. Later on, in May and June 2013, employment declined below its levels recorded in

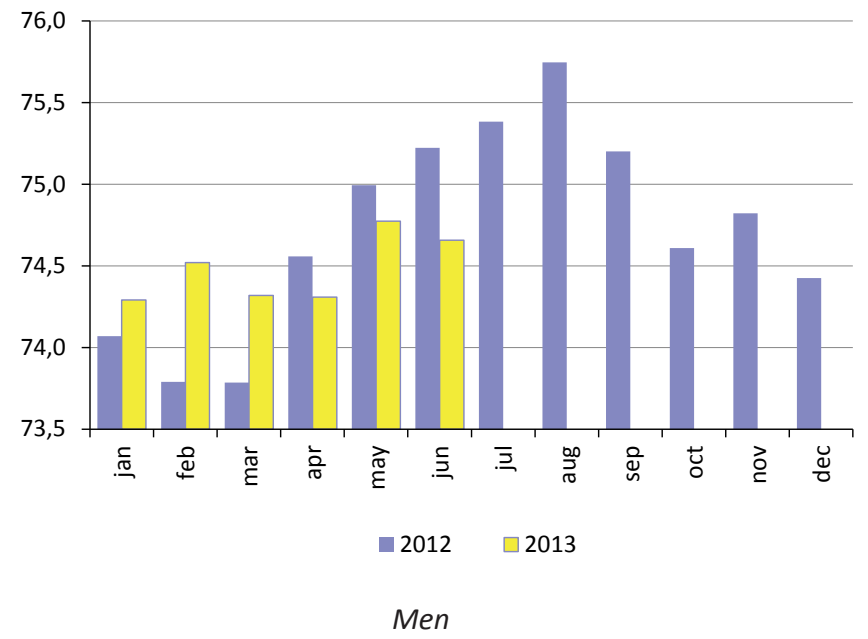

Source: data released by Rosstat.

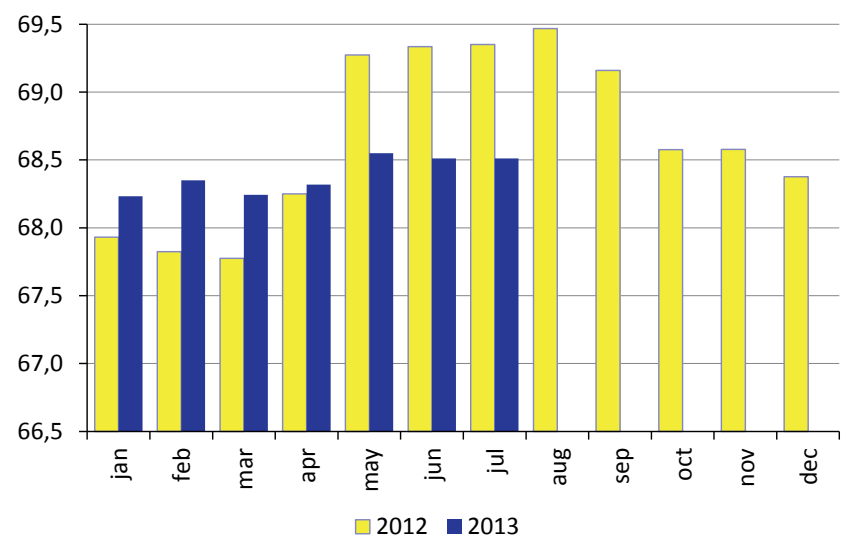

Source: data released by Rosstat.

Fig. 2. The Population's Economic Activity Level in $2012-2013, \%$

the corresponding periods of 2012 by 0.6 and 0.9 p.p. respectively. At the same time, the level of employment dropped lower among women: in May and June 2013, it was lower than its index recorded over the same periods of 2012 by 1.1 and 1 p.p. respectively.

On the whole, the level of employment among women was by more than 10 p.p. lower than among men. At the same time, the employment index for women was significantly dependent on the number of their children. The results of population employment surveys for Q2 2012 and Q2 2013 demonstrate that the level of employment among women aged 20-49 years with three or more children aged under 18 years was by more than 20 p.p. below the same index for women with only one child aged under 18 years. While the employment index for women aged 20-49 years with two children aged under 18 years dropped in Q2 2013 on the corresponding period of 2012 by 2.7 p.p., the same index for women with three or more children rose by 1 p.p., which may in part be explained by the progressive evolution of 'family

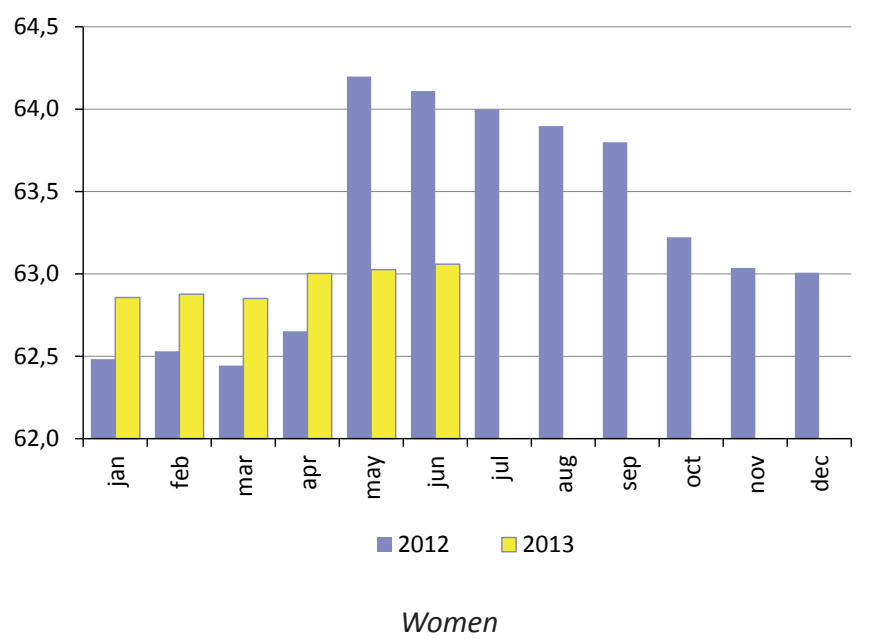

Fig.3. The Population's Economic Activity Level in 2012-2013, \% 
kindergartens', which had made it possible for women with many children to find suitable jobs.

\section{EMPLOYMENT LEVEL FOR WOMEN AGED 20-49 YEARS WITH CHILDREN UNDER 18 YEARS OF AGE, Q2 2012 AND Q2 2013, \%}

\begin{tabular}{|l|l|l|}
\hline $\begin{array}{l}\text { Women with children un- } \\
\text { der } 18 \text { years of age, total }\end{array}$ & 2012 & 2013 \\
\hline $\begin{array}{l}\text { Including those with } \\
1 \text { child }\end{array}$ & 75.3 \\
\hline $\begin{array}{l}2 \text { children } \\
\text { 3 or more children }\end{array}$ & 74.5 & 71.7 \\
\hline $\begin{array}{l}\text { Out of the number of women } \\
\text { with children under 18 years of } \\
\text { age, those with children in the } \\
\text { pre-school age group (0-6 years) }\end{array}$ & 65.7 & 57.7 \\
\hline
\end{tabular}

Source: data released by Rosstat.

Although the level of employment in May and June 2013 was below that recorded in the corresponding periods of 2012, the share of those employed in the 'informal' sector in the total number of employed in May and June 2013 became higher by 0.2 and 0.7 p.p. respectively than the same index for the corresponding periods of 2012. On the whole, the share of those employed in the 'informal' sector in the period from January through June 2013 increased from 18.3 to $20.5 \%$.

The level of unemployment in July 2013 was 5.3\% (when not adjusted by the seasonal factor). Over the period of January-March 2013, the unemployment index was on the decline and fell below its levels in the corresponding periods of 2012 by $0.4-0.6$ p.p. Then, although in June and July 2013 the unemployment index continued on a downward trend, it demonstrated a slight rise on its level in the corresponding periods of 2012.

It should be noted that the unemployment level among the rural population was markedly higher than that for the urban population. Thus, for example, in July 2013 the difference was 1.6 times, and in April 2013-2.1 times.

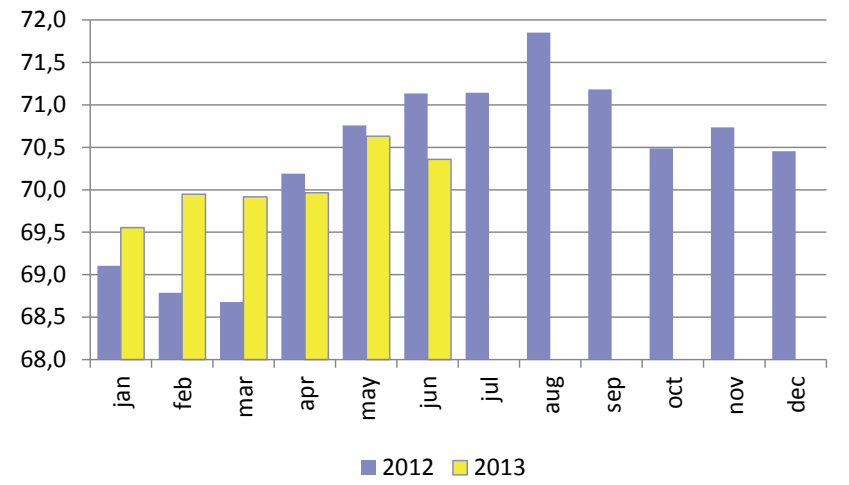

Men

Source: data released by Rosstat.

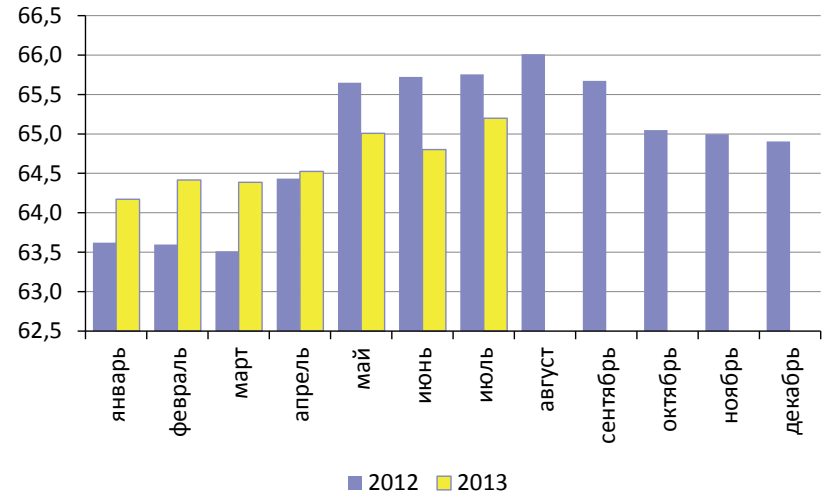

Source: data released by Rosstat.

Fig. 4. Employment Level in 2012-2013, \%

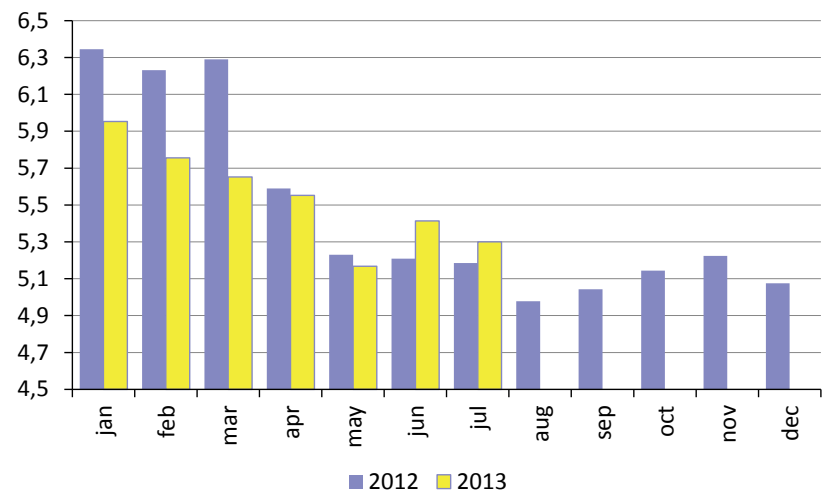

Source: data released by Rosstat.

Fig. 6. Unemployment Level in 2012-2013, \%

The total number of unemployed estimated in accordance with the International Labor Organization's criteria was 4.2 times than the number of unemployed registered by the government unemployment agencies. As of the end of July 2013, a total of 945 thousand people were entered in the unemployment records, which is by $2.6 \%$ less than in June 2013 , and by $13.0 \%$ less than in July 2012 .

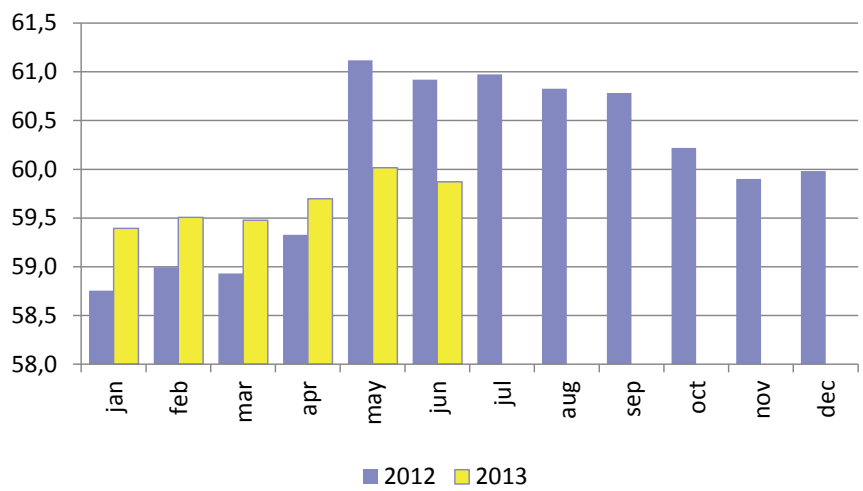

Women

Fig. 5. Employment Level in 2012-2013, \% 